\title{
VIRTUAL COMMUNICATION IN EDUCATIONAL SYSTEM
}

\section{Jana DEPEŠOVÁ}

\begin{abstract}
New concepts that are being applied into the educational system in the Slovak Republic, especially after the school reform from 2008, are supported by the Information and Communication Technologies. There are cases galore where the position of the ICT is dominant in the educational process. Neither technical subjects have not escaped from the abovementioned influence thanks to which an obvious modernization and changes in the educational process has been recorded after implementation of the ICT that bring a set of advantages and benefits into education.
\end{abstract}

Key words: technical education, virtual communication, pedagogical practice.

\section{VIRTUÁLNA KOMUNIKÁCIA VO VZDELÁVACOM SYSTÉME}

Resumé: Nové koncepcie, ktoré sa aplikujú do vzdelávacieho systému na Slovensku najmä po školskej reforme v roku 2008 uplatňujú vo vel'kej miere informačné a komunikačné technológie. V mnohých vyučovacích predmetoch je ich uplatnenie vniektorých prípadoch vo vzdelávaní dominantné. Tomuto vplyvu sa nevyhli ani technické predmety, u ktorých došlo aplikáciou informačných a komunikačných technológií k modernizácií a celkovej zmene vzdelávania. Informačné a komunikačné technológie aplikáciou do vzdelávacieho procesu prinášajú vel'ké množstvo predností a výhod.

Kl'účové slová: technické vzdelávanie, virtuálna komunikácia, pedagogická prax.

\section{1 Úvod}

V početnej odbornej literatúre (napríklad $\mathrm{v}$ prácach Dirnera, Tureka, Burgerovej, Kozíka a iných) sú hodnotené informačné a komunikačné prostriedky zhl'adiska ich pozitívnych a negatívnych vplyvov na edukáciu. Ak máme vyzdvihnút' výhody, ktoré prináša aplikácia informačných technológií do edukačného procesu zameriame sa najmä individualizácia vyučovania, motivácia žiakov, okamžitá spätná väzba, názornost' vo vyučovaní - obraz, zvuk, prezentácie, animácie, objektívnost' hodnotenia žiakov, študentov, možnost' výmeny informácií medzi žiakmi prostredníctvom synchrónnych a asynchrónnych aplikácií, získavanie, resp., poskytovanie informácií $\mathrm{v}$ relatívne krátkom čase, zvyšovanie efektívnosti vzdelávania, využitie IKT ako učebného prostriedku na l'ubovol'nom vyučovacom predmete. Zaradenie IKT do vyučovania však prináša aj niektoré nevýhody, najvýraznejšie sú najmä možnost' vzniku technických, resp. programových problémov počas vyučovania, možnost' získania návykov na počítač ako komunikačný prostriedok a teda získat' poruchu komunikácie, vznikajú závažné problémy v personalizácií (napr. rozvoj tvorivosti je podmienený vzájomnou stimuláciou myšlienok), izolácia, odcudzenie l'udí, možné zdravotné problémy - poruchy zraku, deformácia chrbtice, neurózy, redukcia písanej a hovorenej reči, problémy $\mathrm{v}$ afektívnej oblasti - poruchy v oblasti citovej výchovy, tvorby hodnotového systému.

\section{IKT vo vzdelávaní}

S prihliadnutím na pozitívne a negatívne stránky je zrejmé, že aplikácia IKT do edukácie nemôže nahradit' klasické metódy vzdelávania, ale môže podstatne ovplyvnit' efektivitu vyučovacieho procesu. Je vždy na učitel'ovi, ako využije možnosti, ktoré aplikácia informačných a komunikačných prostriedkov do vyučovacieho procesu umožňuje.

Po prijatí školskej reformy, dochádza v systéme slovenského školstva k posilneniu využívania IKT vo vzdelávaní. Predovšetkým je to dané požiadavkou, že obsah vzdelávania a jeho ciele je potrebné dosiahnut', v prípade technického vzdelávania, v kratšej časovej dotácií s dôrazom na využívanie foriem samoštúdia. Uplatňovanie IKT sa priamo odráža aj v technickom vzdelávaní, pretože technika nemôže ignorovat' existenciu IKT. Technika a prírodovedné vedy sú oblasti, v ktorých sú IKT najlepšie využitel'né.

Vzdelávanie $\quad \mathrm{v}$ technike $\quad \mathrm{z}$ pohl'adu celoživotného vzdelávania sa uskutočňuje $\mathrm{v}$ rámci štruktúry: predprimárne vzdelávanie, 
primárne vzdelávanie, nižšie sekundárne a vy̌̌šie sekundárne vzdelávanie, terciálne vzdelávanie. V tejto štruktúre nadväzujú následne rôzne rekvalifikačné a zdokonal'ovacie kurzy alebo univerzity tretieho veku. V rámci uvedenej štruktúry celoživotného vzdelávania, resp. špecificky celoživotného technického vzdelávania vzniká priestor pre využívanie jednej $\mathrm{z}$ moderných vyučovacích koncepcií s využitím IKT, ktorú nazývame virtuálna komunikácia.

Pri definovaní pojmov virtuálny a komunikácia sa stotožňujeme $\mathrm{s}$ definíciami uvádzanými v literatúre, zvolili sme význam uvádzaný v slovníku cudzích slov od Šalinga (Šaling, 2008), ktorý uvádza nasledovné vysvetlenie pojmov virtuálny - uskutočnitel'ný, realizovaný pomocou elektronických prístrojov, počítačov, komunikácia - dorozumievanie, sprostredkovanie, odovzdávanie informácií medzi subsystémami sústav, proces výmeny informácií. V spomínanej štruktúre technického vzdelávania si pri aplikácií virtuálnej komunikácie do vyučovania zasluhuje pozornost' v každej skupine žiakov. Virtuálna komunikácia je v súčasnosti rozšírená najmä v dištančných formách vzdelávania. Turek (Turek, 2008) uvádza, že ide $\mathrm{v}$ podstate o rozmanité formy systematicky organizovanej výučby na dial'ku prostredníctvom korešpondencie, telekomunikačných médií, satelitného prenosu, elektronickej pošty, pri ktorých dochádza k minimálnym priamym kontaktom medzi učitel'om (lektorom) a samostatne študujúcim. Samotné štúdium prebieha prostredníctvom počítačov, prednášky, semináre, konzultácie a aj skúšky prostredníctvom internetu. Učenie sa realizované prostredníctvom PC nazývame elearning a jeho najväčšou prednost'ou je okrem iného individualizácia vyučovania a učenia sa, t. j. každý žiak má svojho učitel'a, aj ked' tento nemá l’udskú podobu. Virtuálna komunikácia vo vzdelávacom procese je interaktívna komunikácia viacerých účastníkov prostredníctvom počítačových sietí, je jednou $\mathrm{z}$ foriem e-learningu a je práve tým prostriedkom, ktorý dovol'uje reálne uskutočnit' potrebnú komunikáciu medzi univerzitnými pracoviskami, učitel'skou praxou, (základnými a strednými školami) a to bez mimoriadnych dodatočných finančných vstupov. Realizácia výučby na dial'ku bola overená aj na Katedre techniky a informačných technológií PF UKF v Nitre formou videokonferencií VRVS na základe konzultácií medzi katedrami univerzít na Slovensku, na základe výmeny názorov medzi univerzitami v zahraničí (Pol'sko, Česká republika, Mad’arsko), v rámci realizácie kurzu ESF - výučba ECDL - teoretická čast' s ciel'om získat'.

Efektívnost' virtuálnej komunikácie vo vzdelávaní potvrdzujú aj výsledky výskumov na KTIT PF UKF v Nitre, realizovaných v rámci riešenia vedeckých úloh VEGA 1/2541/05 Systém vzdelávania v oblasti technickej výchovy na základných školách $\mathrm{v}$ podmienkach vstupu Slovenskej republiky do Európskej únie, KEGA 3/3108/05 - Centrum dištančného vzdelávania s virtuálnym prostredím, VEGA č. 1/0744/08 Video-konferenčný systém v pedagogickej praxi, KEGA č. 3/6369/08 - Model komunikácie odbornej univerzitnej katedry s pedagogickou praxou $\mathrm{v}$ digitálnom informačnom prostredí.

\section{Virtuálna komunikácia vo vzdelávaní}

Vzdelávacie ciele určujú vedomosti, zručnosti a kompetencie, ktoré by si mladí l'udia mali osvojit' pri dosiahnutí určitého veku, alebo vzdelanostnej úrovne. Učebné osnovy prenášajú tieto ciele do obsahu predmetu, ktorý sa neustále mení. Rada pre vzdelávanie EÚ v správe s názvom Konkrétne ciele vzdelávania a vzdelávacích systémov stanovila tri strategické ciele a to zvýšenie kvality a účinnosti vzdelávania a vzdelávacích systémov v Európskej únii, umožnenie prístupu k štúdiu a vzdelávaniu pre všetkých, otvorenie vzdelávania a vzdelávacích systémov širšiemu svetu. K splneniu týchto ciel'ov má prispiet' okrem iného zlepšenie vzdelávania a odbornej prípravy učitel'ov, zvýšenie počtu uchádzačov prijatých na vedecké a technické odbory štúdia, vytváranie otvoreného vzdelávacieho prostredia a atraktívnejšieho štúdia, ale aj posilnenie spojenia vzdelávania s praxou a výskumom. Dosahovanie ciel'ov technického vzdelávania $\mathrm{v}$ Slovenskej republike vzhl'adom $\mathrm{k}$ technickému vzdelávaniu v ostatných krajinách Európskej únie, je podmienené inováciou obsahu, metód, foriem a prostriedkov edukácie. Zrýchl’ovanie dynamiky technického a ekonomického rozvoja vyvoláva nové spoločenské potreby. Nevyhnutnost' dosahovania vysokej efektívnosti pri utváraní nových poznatkov a vedomostí žiakov vyžaduje, aby technické vzdelávanie bolo koncipované $\mathrm{s}$ uplatňovaním informačných a komunikačných technológií $\mathrm{v}$ najširšom možnom rozsahu.

Vo vyučovacom procese technickej výchovy, resp. techniky je potrebné rešpektovat' špecifikum technického vzdelávania, ktoré sa prejavuje najmä $\mathrm{v}$ tom že integruje teoretickú 
a praktickú stránku vzdelávania. Pri zaradení virtuálnej komunikácie do edukácie je možné simulovat', modelovat' fyzikálne javy a technologické procesy, uskutočnit' prípravu, realizáciu, konkrétny experiment v čo najkratšom čase, realizovat' školské laboratórne a praktické cvičenia, realizovat' prenos najnovších vzdelávacích koncepcií, sprostredkovat' poznatky vedy a pedagogického výskumu, rozširovat' pozitívne skúseností učitel'ov z praxe, realizovat' efektívnu tvorbu vzdelávacích programov pre riadne aj dištančné formy vzdelávania, sprostredkovat realizáciu inovačného vzdelávania vekonomicky výhodných podmienkach, kvalitatívne a efektívne riešit' systém celoživotného vzdelávania, zabezpečit' systém pedagogickej praxe študentov vo virtuálnom prostredí.

\section{Záver}

Aplikácia informačných a komunikačných technológií umožňuje využit' vo vzdelávaní e-learningové metódy, výhodne uskutočnit' vzdialenú výučbu, dištančné formy vzdelávania, riešenie postgraduálneho vzdelávania dospelých, zvyšovanie kvalifikácie jednotlivcov popri zamestnaní, vzdialené externé konzultácie a diskusie. $\mathrm{Aj}$ napriek tomu, že takto uskutočňované vyučovanie si vyžaduje náročnejšiu prípravu na vyučovanie so strany učitel'a ale aj žiaka, vysokokvalitnú elektronickú prípravu učebných textov a praktickej činnosti, osobitnú prípravu testov a simuláciu technologických procesov, možnost' priamej komunikácie v elektronickej sieti, dosiahli informačné a komunikačné technológie taký vysoký stupeň uplatnenia vo vzdelávaní najmä preto, že nezasahujú do edukácie rušivo, sú l'ahko ovládatel'né a sú pre študentov atraktívnou formou vzdelávania.

Využívanie nových prístupov vo vzdelávaní s využitím informačných a komunikačných technológií kladie dôraz na kvalitu vzdelania študentov, budúcich učitel'ov a to $\mathrm{v}$ oblasti ich klasickej prípravy na vyučovanie, ale aj v oblasti prípravy na zvládanie nových metód a postupov, ktoré bude musiet' učitel' využívat' v svojej práci. $\mathrm{K}$ spomenutým trendom sa bude musiet' orientovat' aj d'alšie vzdelávanie učitel'ov, napríklad v oblasti diagnostikovania osobnosti žiaka, študenta, diagnostikovanie učebného procesu, ale aj rozvoja

vlastnej osobnosti. Prioritné ciele, ktoré vychádzajú zo základných koncepcií využívania IKT vo výučbe sú najmä efektívnejšia príprava učitel'a na vyučovanie, príprava učebných textov v elektronickej podobe, kvalitné sprístupnenie učebného obsahu, možnost' vizualizovat' učebný obsah, využívanie nových progresívnych metód a foriem vyučovania, orientovaných na rozvíjanie tvorivej osobnosti žiaka, využívanie kooperatívneho vyučovania, rozvíjanie komunikačných zručností študentov $\mathrm{v}$ interaktívnom vyučovaní $\mathrm{v}$ pedagogickej praxi.

Účinné spojenie teórie $\mathrm{s}$ praxou $\mathrm{v}$ rámci pedagogickej praxe študentov učitel'ských študijných programov si v súčasnosti vyžaduje určitú inováciu existujúcej formy pedagogickej praxe tak, aby popri zachovaniu pozitívnych prvkov súčasnej praxe, boli v nej zohl'adnené aj možnosti, ktoré ponúkajú informačné a komunikačné prostriedky. Využitie virtuálnej komunikácie vo vzdelávaní študentov dovol'uje bez nárokov na osobitné priestory, potrebného času na prepravu na miesta stretnutí, výmenu skúseností medzi zúčastnenými stranami. Hlavným prínosom vzdelávania s uplatnením video-konferenčného systému, je podstatná zmena organizácie vzdelávania, zvýšenie kvality a efektívnosti pedagogickej práce, vytvorenie priestoru komunikácie učitel'skej praxe s odbornými katedrami. Vzdelávanie s podporou video-konferenčného systému - virtuálna komunikácia, sa môže stat' perspektívnou metódou $\mathrm{v}$ procese všeobecného a odborného vzdelávania nielen pre svoju atraktívnost', ale aj vd’aka predpokladanej ekonomickej účinnosti (Kozík, Depešová, 2007b).

\section{Literatúra}

[1] DEPEŠOVÁ, J. a kol. Pedagogická prax s podporou informačných a komunikačných technológií: výstup riešenia projektu VEGA. Videokonferenčný systém $\mathrm{v}$ pedagogickej praxi. Nitra: UKF, 2010.166 s. ISBN 978-80-8094-8276.

[2] KOZÍK. T. a kol. 2006. Virtuálna kolaborácia a e-learning. Nitra: Pedagogická fakulta UKF, 2006. s. 80. ISBN 978-80-8094053-9.

[3] KOZÍK, T. - DEPEŠOVÁ, J. 2007a. Projekt a realizácia modelu videokonferenčného systému $\mathrm{v}$ pedagogickej praxi. In: Technika - informatika - edukácia. Teoreticzne i prakticzne problemy edukacji informatycznej. TOM VIII. Rzeszow, 2007. s. 53 - 59. ISBN 978-83-88845-91-8.

[4] KOZÍK, T. - DEPEŠOVÁ, J. 2007b. Model virtuálnej pedagogickej praxe. In: Zborník Pedagogická prax - súčasnost' a perspektívy. 
Nitra: UKF, 2007. s. 205 - 211. ISBN 987-808094-145-1.

[5] TUREK, I. 2008. Didaktika. Bratislava: Ekonómia. 2008. 595 s. ISBN 978-80-8078-1989.

[6] ŠALING, S. Vel'ký slovnik cudzich slov. Bratislava: Vydavatel'stvo SAMO, 2008. 1184 s. ISBN 978-80-89123-07-0.
Lektoroval: doc. PaedDr. Iveta Šebeňová, PhD.

Jana Depešová, doc. PaedDr. PhD.,

Katedra techniky a informačných technológií,

Pedagogická fakulta UKF, Dražovská cesta 4

Nitra, SR,

tel. 00421376408336

e-mail: jdepesova@ukf.sk 